\title{
ANALISIS ALIRAN ANGIN PADA ATAP MIRING MELALUI UJI SIMULASI FLOW DESIGN
}

\author{
Siti Belinda Amri \\ Jurusan Arsitektur Universitas Halu Oleo, Kendari \\ Email: linda.amri@gmail.com \\ La Ode Abdul Syukur \\ Jurusan Arsitektur Universitas Halu Oleo, Kendari \\ Email:laodeabd@gmail.com
}

\begin{abstract}
Abstrak
Bidang penelitian tentang aliran angin pada bangunan sangat penting baik untuk perencanaan bangunan maupun pemukiman. Aliran angin yang mempengaruhi bangunan memiliki dampak pada ketahanan struktural terhadap angin. Penelitian dilakukan untuk mengetahui nilai drag coefficient atau gaya hambat terhadap angin yang dihasilkan pada atap miring dengan nilai sudut yang berbeda. Metode yang digunakan adalah dengan menguji model atap melalui simulasi CFD (Computational Fluid Dynamic) pada software Autodesk Flow Design. Hasil uji lima atap miring dengan nilai $0^{\circ}$, $15^{\circ}, 30^{\circ}, 45^{\circ}$, dan $60^{\circ}$ menujukkan bahwa semakin besar sudut atap maka semakin besar luas bidang atap yang bersentuhan dengan aliran angin datang, hal ini sejalan dengan nilai average drag coefficient yang dihasilkan. Atap dengan sudut $60^{\circ}$ memiliki luas bidang atap dan nilai average drag coefficient yang tertinggi diantara kelima sudut atap yang diuji, dengan nilai luas $72 \mathrm{~m}^{2}$ menghasilkan nilai average drag coefficient sebesar 1,4. Bangunan dengan nilai drag coefficient yang tinggi memiliki resiko kerusakan struktur yang tinggi akibat angin karena memiliki bentuk yang kurang aerodinamis.
\end{abstract}

Kata-kata Kunci: aliran angin, atap miring, Flow Design, drag coefficient.

\section{ANALYSIS OF WIND FLOW PATTERN ON SLOPED ROOF USING FLOW DESIGN SIMULATION}

\begin{abstract}
The field of research on wind flow on buildings is important for both building planning and planning a residential areas. Wind flow affecting the building has an impact on structural resistance to the wind. The study was conducted to find out the value of drag coefficient or drag force against the wind generated on the sloped roof with different angle values. The method applied by tested the roof model through CFD (Computational Fluid Dynamic) simulation through Autodesk Flow Design software. The test results of five sloped roofs with angle $0^{\circ}, 15^{\circ}, 30^{\circ}, 45^{\circ}$, and $60^{\circ}$ showed that the higher the angle of the roof, the larger the area of the roof in contact with the approaching wind flow. This is in line with the average drag coefficient value generated. The roof with an angle of $60^{\circ}$ has a large roof area and the highest average drag coefficient among the five tested roof angles, with an area of $72 \mathrm{~m}^{2}$ yields and average drag coefficient of 1.4. Buildings with high drag coefficient value have a high risk of structural damage due to wind because it has a less aerodynamic shape.
\end{abstract}

Keywords: wind flow, sloped roof, Flow Design, drag coefficient 


\section{Pendahuluan}

Indonesia adalah negara kepulauan yang beriklim tropis lembab dan negara kepulauan Kondisi iklim dan posisi geografis Indonesia ini menjadi tantangan tersendiri bagi para perancang dalam menentukan desain bangunan. Kejadian cuaca ekstrim pada musim pancaroba yang paling banyak adalah bencana angin puting beliung. Setiap tahun terjadi bencana angin kencang di Indonesia. Sebagian besar korban luka-luka dan meninggal karena tertimpa bagian bangunan yang runtuh akibat tertiup angin. Oleh karena itu dalam perancangan bangunan, harus benar-benar memperhatikan faktor alam, untuk mengantisipasi jatuhnya koban jiwa jika terjadi bencana serupa.

Selain dampak positif, keberadaan angin mampu memberikan dampak negatif pada bangunan. Keberadaan angin mempengaruhi pembebanan bangunan melalui beban angin. Angin dapat mengakibatkan beberapa elemen struktur terlepas, terangkat dan bergeser. Potensi bencana angin di Indonesia terindikasi cukup besar khususnya untuk kategori angin topan. Melihat hasil data perbandingan bencana alam per jenis kejadian selama periode tahun 1815-2014 yang terjadi di wilayah Indonesia, angin puting beliung menempati urutan ke 2 terbesar yaitu $21 \%$. Data dari BNPB, selama tahun 2013 telah terjadi kejadian angin puting beliung di wilayah Indonesia sebanyak 503 kejadian, jumlah meninggal 31 jiwa, luka-luka 171 jiwa, menderita 45.774 jiwa, mengungsi 1.598 jiwa, serta rumah rusak ringan hingga rusak berat sebanyak 26.703 unit (Mujiasih, S \& Primadi, S.T, 2014). Rusaknya struktur bangunan tentu mengakibatkan kerugian lainnya, misalnya harta benda dan bahkan korban jiwa yang terjadi akibat tertimpa reruntuhan bagian bangunan. Sebagian besar korban luka-luka dan meninggal karena tertimpa bagian bangunan yang runtuh akibat tertiup angin. Oleh karena itu dalam perancangan bangunan, harus benar-benar memperhatikan faktor alam, untuk mengantisipasi jatuhnya koban jiwa jika terjadi bencana serupa.

Atap sebagai penutup seluruh ruangan yang ada di bawahnya, sehingga akan terlindung dari panas, hujan, angin dan binatang buas serta keamanan. Faktor iklim menjadi bahan pertimbangan penting dalam merancang bentuk dan konstruksi atap/bangunan. Keberadaan atap pada rumah sangat penting mengingat fungsinya seperti payung yang melindungi sisi rumah dari gangguan cuaca (panas, hujan dan angin). Oleh karena itu, sebuah atap harus benar-benar kokoh/kuat dan kekuatannya tergantung pada struktur pendukung atap.

Beberapa penelitian sebelumnya mengenai pengaruh bentuk-bentuk atap terhadap angin dilakukan dengan menggunakan metode Wind Tunnel ataupun dengan simulasi CFD. Penelitian tersebut diantaranya; penelitian yang dilakukan oleh Guirguis, El-Aziz, \& Nassief (2007) yang menganalisis static force pada bentuk atap pelana dengan sudut-sudut berbeda, penelitian Driss, Driss, \& Kammoun (2014) menganalisis berdasarkan bentuk atap sederhana, datar dan arched, serta Tominaga et al (2015) menganalisis aliran angin berdasarkan sudut dari perbandingan antara ketinggian dan lebar atap. Penelitian mengenai bentuk atap bertujuan untuk mendapatkan bentuk atap yang efektif terhadap daya tahan khususnya ketahanan terhadap angin, karena ketahanan terhadap angin akan mempengaruhi bentuk dan stuktur suatu bangunan sehingga mampu beradaptasi pada kondisi angin kencang. Melalui penulisan ini, akan dibahas bagaimana pengaruh penggunaan atap pelana dengan sudut-sudut yang berbeda terhadap daya tahan atap bangunan sederhana satu lantai.

\section{Kajian Pustaka}

\section{Aliran Angin Pada Atap}

Atap adalah bagian paling atas dari suatu bangunan, yang melindungi gedung dan penghuninya secara fisik maupun metafisik. Menurut (Lippsmeier, 1997), atap merupakan bagian terpenting dari sebuah bangunan. Berdasarkan bidang dan orientasinya, atap adalah bagian bangunan yang paling banyak terkena cahaya, dan merupakan bagian yang paling bertanggung jawab terhadap kenyamanan ruangan dan juga terhadap kerusakan akibat gempa dan angin topan. Secara garis besar, terdapat 3 jenis atap, yakni atap datar, atap miring, dan atap lengkung. Jenis atap miring adalah jenis 
atap yang umum digunakan di Indonesia, karea bentuk atap ini sesuai dengan iklim Indonesia yakni hangat lembab dengan curah hujan tinggi.

Aliran udara (angin) adalah udara yang bergerak (Szokolay, 1980) karena adanya perbedaan tekanan di permukaan bumi. Lebih lanjut Boutet (1987) membagi pola aliran udara atas 3 kategori, yakni pola aliran udara laminar (berlapis) yang cenderung sejajar dan mudah diprediksi, pola aliran udara turbulen (bergolak) yang acak dan susah diprediksi, dan pola aliran udara separated (terpisah) yang kecepatan anginnya berkurang walaupun tetap bergerak sejajar. Selain ketiga pola aliran udara ini, Lechner (2007) menambah pola aliran udara eddy (berpusar). Sewaktu angin mencapai permukaan bangunan, ia akan memadatkan dan menciptakan tekanan positif (+) (windward). Kemudian udara akan dibelokkan ke sisi bangunan tersebut, sehingga tercipta tekanan negatif (-) (leeward). Kemiringan atap bangunan akan menentukan dimensi bayangan angin (leeward) dan olakan (eddy) yang terjadi di bayangan angin tersebut. Kemiringan atap diukur berdasarkan perbandingan antara tinggi atap dan setengah lebar atap.

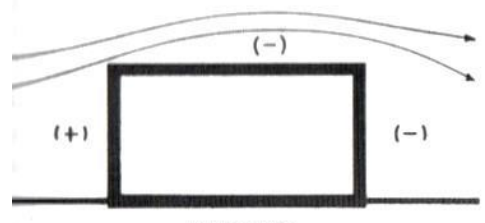

ATAP DATAR

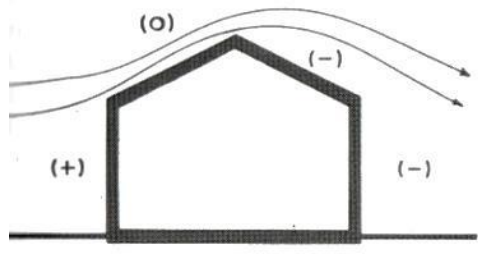

Gambar 1: Tekanan Yang Terjadi Pada Atap Bergantung Pada Kelandaian Atap Sumber: Lechner, 2007

Lebih lanjut, menurut Boutet (1987), aliran udara pada skala bangunan dipengaruhi oleh beberapa hal, antara lain: bangunan itu sendiri, vegetasi di sekitar bangunan, pagar di sekitar bangunan, dan bangunan sekitarnya. Konfigurasi dan orientasi bangunan terhadap arah datangnya angin mempengaruhi pola pergerakan aliran udara dan kecepatan angin. Adapun pada bangunan itu sendiri, terdapat beberapa faktor yang berpengaruh terhadap pola aliran udara dan kecepatan angin, seperti konfigurasi, orientasi, tinggi, teritis, bentuk atap, dan bentuk-bentuk arsitektural lainnya.

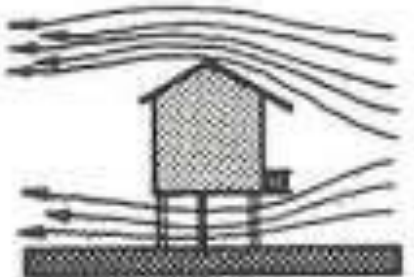

(a)

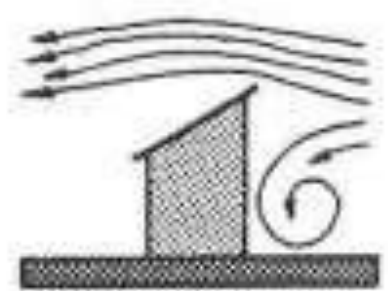

(b)

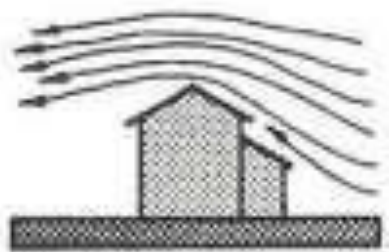

(c)

Gambar 2: Aliran Udara Pada Konfigurasi Dan Orientasi Bangunan Yang Berbeda Sumber: Boutet, 1987

\section{Simulasi Flow Design}

Simulasi dan model pada riset arsitektur digunakan sebagai salah satu strategi penelitian yang berhubungan dengan skala ruang dan kerumitan lingkup penelitian. Secara umum, strategi simulasi 
dan model dapat digunakan dalam pengembangan teori atau menguji suatu teori (Groat dan Wang, 2002). Karakteristik aliran angin dan perpindahan temperatur di sekitar atap dianalisis dengan metode CFD (Computational Flow Design). Program komputer (software) yang digunakan dalam pengujian kinerja aliran udara ini adalah Program Autodesk Flow Design. Software ini dapat digunakan untuk menganalisis aliran fluida pada ruang tiga dimensi dan menganalisis pergerakan aliran udara di dalam/luar ruangan. Computational Fluid Dynamics (CFD) adalah program simulasi untuk memprediksi aliran udara atau angin (Baskaran, 1996).

Pada dasarnya, terdapat berbagai jenis program simulasi CFD. Salah satunya adalah Autodesk Flow Design. Metode kerja Flow Design pada dasarnya sama dengan CFD. Flow Design adalah sebuah aplikasi "virtual wind tunnel." Aplikasi ini membantu seorang desainer atau perencana model memvisualisasikan aliran angin eksternal dengan jelas. Flow Design berfokus pada aliran yang lebih lambat dari pada kecepatan suara. Aliran ini disebut aliran subsonik. Aliran ini sesuai digunakan pada objek otomotif, barang-barang konsumsi, bidang arsitektural, dan pesawat terbang (https://knowledge.autodesk.com).

Flow Design secara otomatis mengkonfigurasi terowongan angin berdasarkan ukuran dan bentuk model. Anda dapat mengubah dimensi terowongan angin ataupun orientasi objek sesuai dengan ukuran dan orientasi model yang diuji. Flow Design bekerja dengan menggunakan pemecah aliran transien. Aliran transien akan menciptakan beberapa variasi saat simulasi berjalan (https://knowledge.autodesk.com). Sementara itu, visualisasi hasil simulasi dapat ditampilkan dengan metode 2D dan 3D. Garis alir di sekitar model uji menunjukkan pergerakan udara di seluruh terowongan angin virtual. Hasil yang dihasilkan oleh Flow Design membantu seseorang memahami bagaimana angin bergerak di sekitar model sehingga membantu pengambilan keputusan dalam mendesain. Selain itu, diperlukan pengetahuan untuk memahami dan menafsirkan hasil uji karena tanpa adanya pengetahuan dasar maka hasil analisis akan sulit terbaca. Salah satu pengetahuan yang harus dimiliki adalah pengetahuan tentang aliran fluida angin.

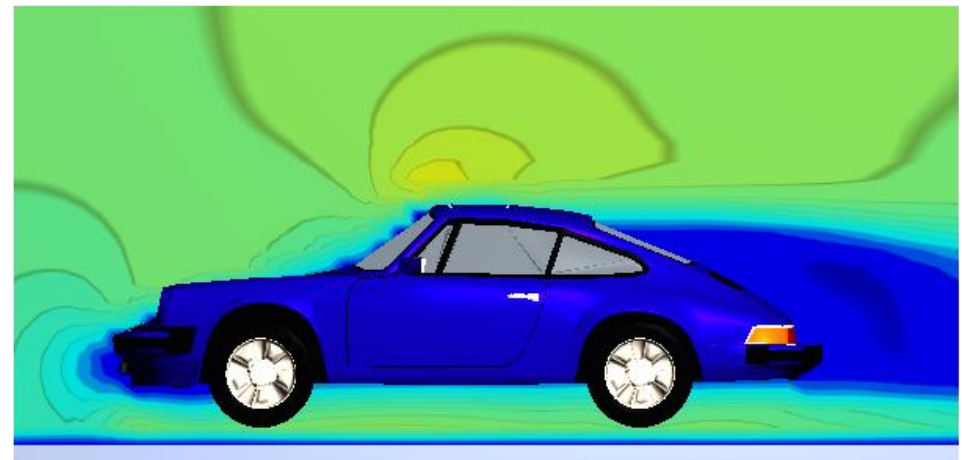

Gambar 3: Contoh Visualisasi Aliran Angin Secara 2D

Sumber: https://knowledge.autodesk.com, diakses 2017

\section{Drag Coefficient}

Besarnya beban angin yang bekerja pada struktur bangunan tergantung dari kecepatan angin, rapat massa udara, letak geografis, bentuk dan ketinggian bangunan, serta kekakuan struktur. Bangunan yang berada pada lintasan angin akan menyebabkan angin berbelok atau dapat berhenti. Sebagai akibatnya, energi kinetik dari angin akan berubah menjadi energi potensial, yang berupa tekanan atau hisapan pada bangunan. Berhubung beban angin akan menimbulkan tekanan dan hisapan, maka berdasarkan percobaan-percobaan, telah ditentukan koefisien-koefisien bentuk tekanan dan hisapan untuk berbagai tipe bangunan dan atap. Salah satu koefisien untuk menentukan nilai hambatan pada suatu objek, dalam hal ini adalah atap adalah nilai drag coefficient.

Satuan untuk menentukan besarnya tekanan angin terhadap suatu objek disebut sebagai Force coefficient. Force coefficient merupakan hasil dari koefisien non-dimensional seperti total tenaga 
angin pada suatu benda. Perlu diketahui apabila gaya berada searah dengan aliran angin, maka koefisien nondimensional akan disebut sebagai drag coefficient $\left(\mathrm{C}_{\mathrm{d}}\right)$, dan apabila gaya tegak lurus terhadap arah aliran angin maka koefisien non dimensional akan disebut sebagai lift coefficient $\left(\mathrm{C}_{1}\right)$ (Bhandari, 2011). Dalam ilmu fluida, drag coefficient sering diasosiasikan dengan gaya aerodinamis dan hidrodinamis. Jika nilai koefisien hambat suatu objek rendah, maka nilai hambatan aerodinamisnya juga rendah. Bentuk yang aerodinamis membuat pergerakan aliran udara di sekitar objek menjadi lancar. Dengan kata lain, untuk menjadi objek yang aerodinamis, sebuah objek harus memiliki nilai drag coefficient yang rendah.

Adapun persamaan yang digunakan adalah untuk menghitung nilai drag coefficient yakni (Bhandari, 2011):

$$
c_{\mathrm{d}}=\frac{2 F_{\mathrm{d}}}{\rho v^{2} A},
$$

Di mana:

$\mathrm{c}_{\mathrm{d}}:$ drag coefficient

$\mathrm{F}_{\mathrm{d}}$ : drag force, yaitu gaya yang bekerja searah aliran fluida $(\mathrm{N})$

$\rho$ : massa jenis fluida $\left(1,2 \mathrm{~kg} / \mathrm{m}^{3}\right.$ untuk udara dalam kondisi NTP (normal pressure temperature air)

$v$ : kecepatan fluida $(\mathrm{m} / \mathrm{s})$

A : luas area dari benda yang dilalui $\left(\mathrm{m}^{2}\right)$

\section{Metode Penelitian}

Penelitian ini merupakan penelitian deskriptif untuk menjelaskan pengaruh bentuk-bentuk atap miring terhadap pola aliran angin. Selanjutnya, penentuan pola aliran angin dilakukan dengan simulasi terhadap beberapa variabel atap dengan bantuan program komputer CFD. Hasil yang diperoleh kemudian didistribusikan dalam bentuk tabel, gambar dan grafik, kemudian dievaluasi.

Adapun peubah/variable yang akan diamati dan diukur dalam kegiatan penelitian ini adalah: Variabel bebas yakni bentuk atap tradisional di Indonesia, adapun bentuk atap terpilih adalah jenis atap pelana. Jenis atap pelana diuji berdasarkan besar sudut atap yakni $0^{\circ}, 15^{\circ}, 30^{\circ}, 45^{\circ}$, dan $60^{\circ}$, seperti terlihat pada gambar 1 . Sedangkan variabel terikat terdiri atas pola aliran angin di sekitar atap dan besar koefisien aerodinamis model uji yang terlihat dari nilai drag force.
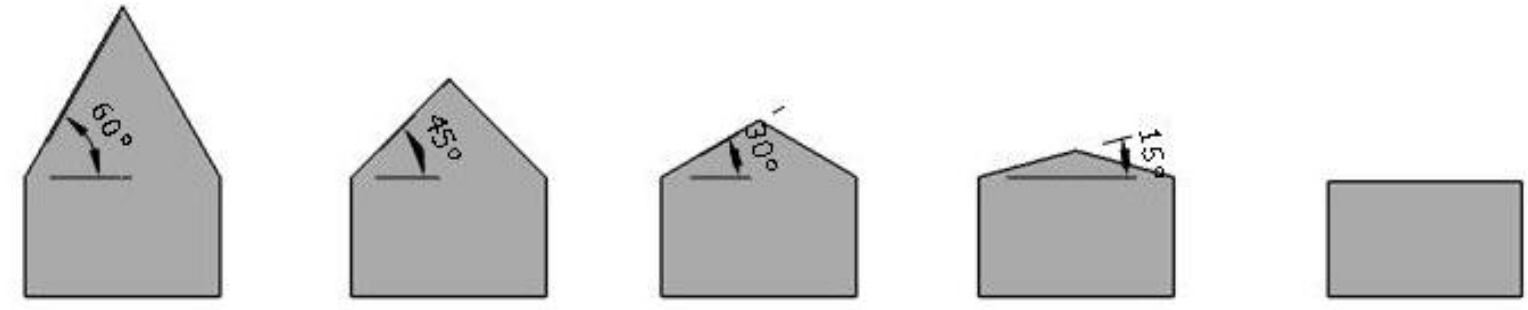

Gambar 4: Besar Sudut Atap Miring Yang Diuji

Sumber: Analisa, 2017

Model uji awalnya dibuat pada software modeling SketchUp atau AutoCad, model kemudian dieksport ke dalam format file 3ds agar bisa digunakan di software Flow Design. Setelah itu, jalankan software Flow Design. Software ini hanya bisa berjalan dengan koneksi internet. Selanjutnya, dilakukan pengaturan dimensi dan kecepatan angin wind tunnel. Simulasi aliran angin dalam Flow Design mengadaptasi sistem pengujian yang dilakukan pada wind tunnel. Aliran angin dalam wind tunnel diatur pada kecepatan $3 \mathrm{~m} / \mathrm{s}$, yakni kecepatan angin tertinggi yang sering ditemui di wilayah perkotaan. Lamanya waktu simulasi tidak bisa ditentukan, karena hasil simulasi sudah bisa terlihat walaupun dalam kondisi simulasi yang belum stabil. Akan tetapi, penentuan hasil dan keputusan desain sebaiknya dilakukan setelah simulasi mencapai tingkat stabilitas. Tingkat stabilitas 
simulasi bergantung pada dimensi dan tingkat kerumitan objek uji. Pada awal setiap simulasi, akan sering terlihat hasil dan visualisasi berubah dengan cepat. Variasi awal ini adalah bagian dari proses perhitungan dan merupakan hasil dari proses komputasi. Seiring arus komputasi berjalan, efek transien pun menjadi kurang jelas sehingga simulasi berlanjut hingga mencapai stabilitas.

Saat simulasi model pertama kali dijalankan, status simulasi tercatat sebagai Unknown. Saat proses pada Flow Design tengah menghitung hasil simulasi, status tercatat sebagai Transient. Hal ini menunjukkan bahwa hasilnya masih dapat berubah. Ketika hasil simulasi berhenti berubah dalam toleransi berdasarkan ukuran model, ukuran voxel (grid), dan kecepatan aliran, status pun berubah menjadi Stabilized. Ini berarti bahwa aliran fluida tersebut telah mencapai kondisi kondisi mapan dan tidak lagi berubah. Jika status telah terbaca Stabilized, setelah itu anda baru bisa mulai menilai hasilnya.

Data kemudian diolah dengan pendekatan visual analisis dan juga statistik deskriptif untuk masing-masing jenis sudut atap. Analisis data dilakukan dengan memperhatikan beberapa hal berikut ini: 1) hasil visualisasi aliran udara; 2) nilai drag force dan drag coefficient.

\section{Hasil dan Pembahasan}

\section{Visualisasi Tekanan Udara}

Analisis simulasi menggunakan metode analisis 2D. Sebuah bidang datar ditempatkan memotong objek uji. Hal ini dilakukan untuk melihat tekanan udara yang terjadi secara 2D tepat di tengah-tengah objek. Visualisasi tekanan udara ditunjukkan melalui pewarnaan grayscale dimana semakin mendekati warna hitam (gelap) menujukkan tekanan udara rendah, sedangkan warna lebih terang atau mendekati warna putih menunjukkan tekanan udara sebaliknya, tinggi.

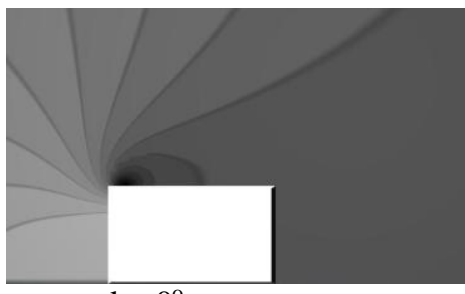

sudut $0^{\circ}$

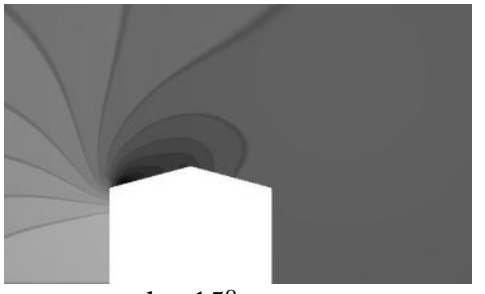

sudut $15^{\circ}$

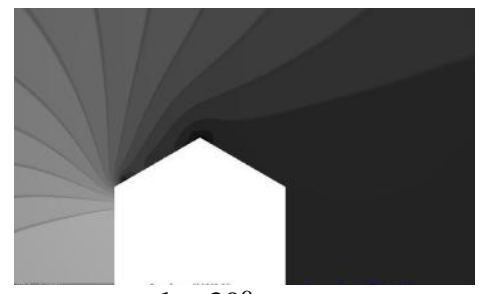

sudut $30^{\circ}$

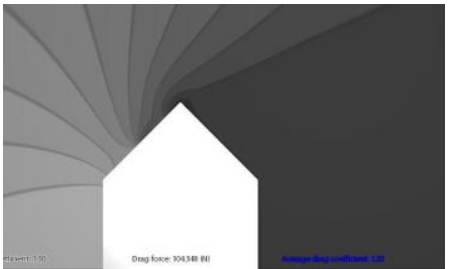

sudut $45^{\circ}$

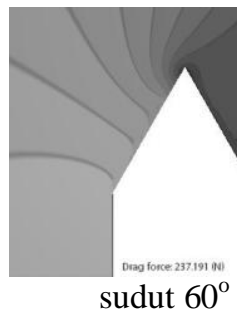

Gambar 5: Visualisasi Tekanan Udara Di Sekitar Permukaan Atap

Sumber: Hasil simulasi Flow Design, 2017

Telah dikemukakan sebelumnya oleh Boutet (1987) bahwa salah satu faktor yang mempengaruhi kecepatan angin di sekitar bangunan adalah bentuk bangunan itu sendiri. Visualisasi tekanan udara (air pressure) yang dihasilkan dari permodelan Flow Design terlihat pada gambar 5. Berdasarkan gambar visualisasi tekanan udara (Pa) pada gambar tersebut, terlihat bahwa semakin tinggi sudut atap, maka tekanan tertinggi akan berpindah dari sudut bagian depan perlahan-lahan ke bagian belakang bangunan. Selain itu, daerah bagian belakang bangunan merupakan bagian yang memiliki tekanan udara paling rendah. Daerah bertekanan rendah pada bangunan dengan sudut $15^{\circ}$ terletak pada sisi atap miring bagian depan. Setelah itu pada sudut $30^{\circ}$, terlihat tekanan terendah terletak pada bagian tengah (nok atap) menuju ke bagian belakang. Pada sudut $45^{\circ}$, tekanan udara berpindah ke sisi menuju atap miring bagian belakang. 
Tabel 1. Nilai average drag coefficient dan drag force

\begin{tabular}{ccc}
\hline Variabel atap & Drag force & Avg drag coefficient \\
\hline $0^{\circ}$ & 20.754 & 0,8 \\
$15^{\circ}$ & 35.851 & 0,89 \\
$30^{\circ}$ & 61.287 & 0,98 \\
$45^{\circ}$ & 101.852 & 1,2 \\
$60^{\circ}$ & 235.121 & 1,4 \\
\hline
\end{tabular}

Sumber: Analisis, 2017

Semetara itu, kadar ketahanan suatu objek terhadap aliran angin dapat dilihat dari nilai drag coefficient. Tabel 1 merupakan hasil nilai drag force dan nilai drag coefficient yang diperoleh melalui simulasi. Terlihat bahwa nilai drag force dan drag coefficient memiliki pola yang sama, semakin tinggi nilai drag force, maka semakin tinggi pula drag coefficientnya. Dari tabel 1 terlihat bahwa semakin tinggi besar sudut maka semakin tinggi pula bangunan. Nilai besar sudut dan ketinggian bangunan juga sejalan dengan nilai drag coefficient. Semakin besar sudut atap bangunan maka semakin besar pula nilai drag coefficientnya atau nilai koefisien hambatnya. Nilai drag coefficient terendah diperoleh pada bangunan bersudut $0^{\circ}$ dengan nilai 0,8 , sedangkan nilai drag coefficient tertinggi diperoleh pada sudut atap $60^{\circ}$ dengan nilai 1,4 .

Suatu objek yang memiliki nilai koefisien hambat tinggi maka akan memiliki gaya arerodinamis yang rendah. Objek tersebut sifatnya menahan laju angin. Jika suatu objek tidak mampu menahan aliran angin, maka dapat mengakibatkan terangkatnya atau bergesernya objek tersebut. Kondisi inilah yang merupakan contoh kerusakan bangunan akibat angin. Beberapa kerusakan yang diakibatkan oleh tekanan dan hisapan angin diantaranya adalah atap akan terangkat atau melayang, badan bangunan akan menjadi miring, dan bangunan dengan struktur sambungan dinding dan atap yang kuat akan membuat bangunan terangkat/terbanting.

Tabel 2. Nilai lebar diagonal dan luas atap

\begin{tabular}{ccc}
\hline Variabel atap & $\begin{array}{c}\text { Lebar diagonal } \\
\text { atap }(\mathbf{m})\end{array}$ & $\begin{array}{c}\text { Luas atap } \\
\left(\mathbf{m}^{\mathbf{2}}\right)\end{array}$ \\
\hline $0^{\circ}$ & 6 & 36 \\
$15^{\circ}$ & 6,25 & 37,5 \\
$30^{\circ}$ & 6,97 & 41,82 \\
$45^{\circ}$ & 8,57 & 51,42 \\
$60^{\circ}$ & 12 & 72 \\
\hline
\end{tabular}

Sumber: Analisis, 2017

Sudut kemiringan atap rumah yang umum digunakan di Indonesia adalah $22,5^{\circ}-30^{\circ}$. Di Indonesia, jenis atap bersudut $45^{\circ}$ mulai ditinggalkan, terlebih lagi atap bersudut $60^{\circ}$ sudah sangat jarang ditemukan. Hal ini dikarenakan tipe atap runcing (sudut besar) sangat cocok untuk daerah bersalju sedangkan Indonesia adalah negara beriklim tropis yang tidak mengenal fenomena salju. Selain itu, faktor pemeliharaan dan pemasangan atap runcing cenderung lebih sulit dibandingkan atap landai, khususnya jika menggunakan material penutup atap genteng. Sudut atap yang terlalu rendah (atap landai) tidak terlalu cocok di Indonesia, karena rentan terjadi rembesan pada atap karena air hujan lambat mengalir. Disamping itu, rumah-rumah di Indonesia membutuhkan ruang transisi dengan luasan yang memadai setelah atap untuk mereduksi panas akibat terik matahari. Semakin landai atap maka ruangan di bawahnya semakin panas.

Berdasarkan persamaan 1, untuk menghitung nilai drag coefficient salah satu faktor yang berpengaruh adalah luas bidang (A) yang bertemu dengan aliran fluida (angin). Semakin besar sudut bangunan maka lebar diagonal atap akan besar pula. Lebar diagonal mempengaruhi besarnya luas 
bidang atap semakin besar. Tabel 2 merupakan nilai lebar diagonal dan besar luasan bidang atap pada setiap sudut bangunan. Tabel tersebut menujukkan nilai lebar diagonal atap yang bersudut $60^{\circ}$ merupakan yang paling besar, sehingga atap bersudut $60^{\circ}$ dengan panjang bangunan 6 meter akan menghasilkan luas bidang atap sebesar $72 \mathrm{~m}^{2}$. Bidang atap yang besar berarti luas bidang yang bersentuhan langsung dengan angin (frontal area) pun semakin besar. Luas bidang yang besar semakin menghambat aliran udara yang akan menaikkan nilai pada nilai Cd (drag coefficient). Untuk meminimalkan nilai drag coefficient, beberapa hal dapat dilakukan diantaranya meminimalkan luas bidang yang bersentuhan langsung dengan angin. Pada atap bangunan yakni dapat dilakukan dengan memperkecil sudut atap. Selain itu, dapat pula dilakukan dengan mengurangi kecepatan angin yang menabrak objek (v) dengan memberikan penghalang di bagian arah datangnya angin. Siasat ini dapat dilakukan jika suatu bangunan harus tetap menggunakan atap bersudut besar.

\section{Kesimpulan}

Berdasarkan hasil analisis data diperoleh kesimpulan bahwa pada posisi tekanan udara yang rendah di permukaan atap berubah-ubah sesuai dengan sudut bangunan. Selain itu, sudut juga mempengaruhi nilai drag coefficient yang diperoleh. Semakin besar sudut suatu bangunan berarti semakin tinggi pula ketinggian bangunan yang secara langsung membuat semakin luas bidang yang bersentuhan langsung dengan angin datang. Bangunan dengan sudut $60^{\circ}$ memiliki nilai luas bidang atap yang besar yakni $72 \mathrm{~m}^{2}$ serta nilai drag coefficient atau gaya hambat yang paling besar yakni 1,4. Hal ini berarti atap dengan sudut yang besar (atap runcing) dapat dikategorikan sebagai bangunan dengan gaya aerodinamis terendah atau merupakan jenis bangunan yang beresiko tinggi mengalami kerusakan akibat angin.

\section{Ucapan Terima Kasih}

Ucapan terima kasih ditujukan kepada DRPM DIKTI dan LPPM Universitas Halu Oleo sehingga penelitian dan penulisan karya ilmiah ini dapat terlaksana melalui bantuan hibah skema Penelitian Dosen Pemula Tahun Anggaran 2017 dengan Nomor Kontrak 611/UN29.20/PPM/2017.

\section{Daftar Pustaka}

Autodeks Help (2015), Get Started With Autodesk Flow https://www.autodesk.com/products/flowdesign/overview (diakses tanggal 5 November 2017)

Bhandari NM, Krishna P. (2011) An Explanatory handbook on proposed IS- 875 (Part 3): Wind loads on buildings and structure. IITK-GSDMA Project on Building Codes.

Boutet, T. (1987). Controlling Air Movement. New York: McGraw Hill.

Chung, TJ., (2010), Computational Fluid Dynamic. Cambridge: Cambidge University Press.

Driss, S., Driss, Z., \& Kammoun, I. K. (2014). Impact of Shape of Obstacle Roof on the Turbulent Flow in a Wind Tunnel. American Journal of Energy Research, 90-98.

Groat, Linda N., David Wang (2002), Architectural Research Methods, New York: John Wiley and Sons.

Guirguis, N., El-Aziz, A. A., \& Nassief, M. (2007). Study of wind effects on different buildings of pitched roofs. Desalination, 190-198.
Lechner, N. (2007). Heating, Cooling, Lighting: Metode Desain untuk Arsitektur. Jakarta: Rajawali.

Lippsmeier, G. (1997). Bangunan Tropis. Jakarta: Erlangga.

Mujiasih, S., \& Primadi S.T., (2014), Analisis Kejadian Puting Beliung Tanggal 11 Desember 2013 di Wilayah Denpasar Bagian Selatan-Bali, Prosiding Workhop Operasional Radar dan Satelit Cuaca, Jakarta: BMKG.

Stathopoulos and B.A. Baskaran, (1996) "Computer simulation of wind environmental conditions around buildings", Engineering Structures, 18(11), 876-885.

Szokolay, N. V. (1980). Environmental Science Handbook. New York: Wiley.

Tominaga, Y., Akabayashi, S., Kitahara, T., \& Arinami, Y. (2015). Air flow around isolated gable-roof building with different roof pitches: Wind Tunnel experiments and CFD Simulation. Building and Environment, 204-213. 